\title{
COLLECTIVE ACTION FOR WATER HARVESTING IRRIGATION IN THE LERMA-CHAPALA BASIN, MEXICO
}

Christopher A. Scott and Paula Silva-Ochoa

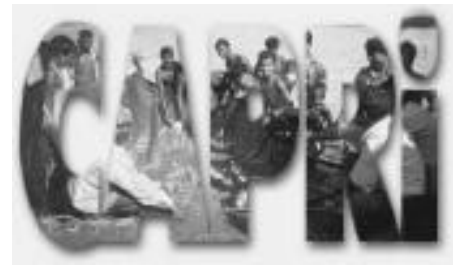

\section{CGIAR Systemwide Program on Collective Action and Property Rights \\ www.capri.cgiar.org}

Secretariat:

International Food Policy Research Institute 2033 K Street, N.W.

Washington, D.C. 20006 U.S.A.

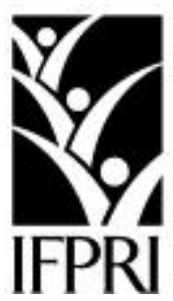

OCTOBER 2001

CAPRi Working Papers contain preliminary material and research results, and are circulated prior to a full peer review in order to stimulate discussion and critical comment. It is expected that most Working Papers will eventually be published in some other form, and that their content may also be revised 


\begin{abstract}
Water and watersheds are difficult to separate for management purposes. Providing irrigation as a supplement to rainfall for crop production requires considerable collective action at the watershed level to mobilize labor and other resources, as well as to make decisions and implement the distribution of benefits. Small-scale water harvesting irrigation systems in Mexico have endured for centuries. They now face considerable challenges with changes in the ejido property rights over land and water, the growing importance of alternative sources of livelihoods, and increasing scarcity and competition for water within the river basins. Two case studies of water harvesting irrigation systems in the Lerma-Chapala Basin illustrate the response of communities to these challenges. In the first community, earlier collective action to build the irrigation reservoir provided a platform to address catchment resource use. Water here was less scarce than in the second community, allowing for good crop productivity through sufficient irrigation. Water scarcity in the second community increases crop risk; expected sorghum yields during the period of field study did not justify harvesting costs and the crop was used as stover. Members of the second community increased their dependence on off-farm income sources, but still responded collectively to external forces claiming the water.
\end{abstract}

Keywords: irrigation, watershed, water harvesting, water, collective action, property rights, Mexico 


\section{TABLE OF CONTENTS}

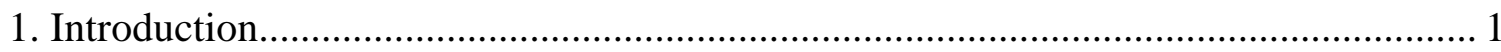

2. Water Harvesting in Mexico: Background and Outlook ........................................ 4

3. Lerma-Chapala Basin Water Competition......................................................... 12

4. Field Studies of Water Harvesting Irrigation.................................................. 15

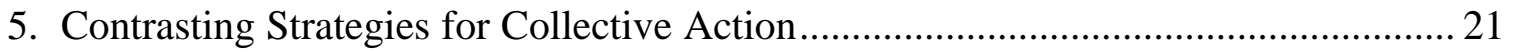

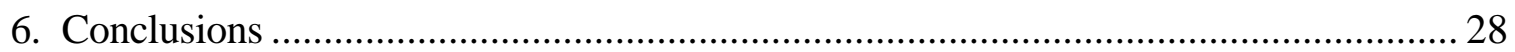

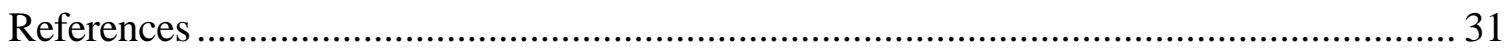




\title{
COLLECTIVE ACTION FOR WATER HARVESTING IRRIGATION IN THE LERMA-CHAPALA BASIN, MEXICO
}

\author{
Christopher A. Scott ${ }^{1}$ and Paula Silva-Ochoa ${ }^{2}$
}

\section{INTRODUCTION}

Water harvesting irrigation $(\mathrm{WHI})^{3}$ systems represent a critical though often overlooked watershed resource use strategy practiced in a wide range of geographical, climatic, social and economic contexts (Oweis et al. 1999; Agarwal and Narain 1997; Scott 1994). Given their dispersed nature, relatively small size and suitability under resource-poor conditions, WHI are not likely to attract significant external support or imposed management, but they do offer considerable potential for poverty eradication (Van Koppen 1998) and equitable resource access (Merrey 1997).

While some WHI systems in developing countries may be built and operated by individual landowners, the level of land, labor, capital and "representational" resources that must be mobilized for constructing, maintaining, and managing such WHI systems requires a high degree of collective action Further, because WHI functions in a larger watershed context, which includes land, forests, and other resources along with water for multiple purposes including irrigation, these systems are often managed as common property resources. As such, their sustainability depends not just on technical or

\footnotetext{
1 Principal Researcher, International Water Management Institute, c.scott@ cgiar.org

2 M.Sc. candidate, International Institute for Infrastructural, Hydraulic and Environmental Engineering, polsil@hotmail.com

3 By water harvesting, we refer to the capture, diversion, storage and subsequent use of surface runoff generated in watersheds. By this definition, the watershed as a unit is considered to include both the upstream catchment and downstream use of water.
} 
environmental factors, but also on effective institutions to mobilize labor and other resources, as well as to make decisions and implement the distribution of benefits.

A combination of factors shapes the ways in which WHI is managed-factors that are both specific to the resource and users group (water scarcity, social stratification, and organization) and generic to the larger context in which these are embedded (water competition, government intervention, and economic forces). In cases where irrigation is intended to supplement rainfall, the WHI strategy may simply be to avert total crop failure. On the other hand, where irrigation is intended to be the primary water supply to the crop (particularly in dry season cultivation), water must be allocated to ensure greater crop productivity. Both strategies may apply in the same WHI system in different seasons. Nevertheless, each requires a distinct set of water allocation and distribution rules or agreements that are conditioned by the social and economic contexts in which WHI operates.

The adoption of resource management practices is conditioned by resource tenure and property rights systems (Place and Swallow 2000) and labor constraints that may limit the time individuals or households are able to spend on management of collective resources. Social, class and gender dynamics also clearly mediate access to these resources and fundamentally shape the rules and conventions that determine water allocation, as will be shown in the case studies.

Many farmer-managed irrigation systems have been in operation for centuries (and have been the subject of study for decades_-see Ostrom 1992; Wade 1994). However, the survival of such systems is challenged by changing property rights regimes, livelihood strategies, and growing scarcity and competition over water resources. In 
Mexico, the ejidos that have held land and water resources as common property since the 1930s are undergoing major reforms that will weaken their collective control over resources. Moreover, we generally expect users to show a stronger commitment to common property management where the resource is central to their survival (Baland and Platteau 1996; Wade 1994), which would imply that diversification of incomes out of agriculture would decrease the level of involvement in WHI. While increasing water scarcity may increase participation in irrigation management up to a point, it also brings different groups from a basin into greater contact with each other and calls for greater negotiations or interaction over water supplies. In this paper, we examine how these factors affect management in two WHI systems in the Lerma-Chapala Basin in Mexico.

In the context of water-scarce river basins where demand for water exceeds supply and "closed basins" where there is no outflow of water that is not already committed to downstream uses (often with pre-established rights), there are clear upstream-downstream tradeoffs associated with WHI water extractions. ${ }^{4}$ As demand for water increases downstream, political and economic pressure may be brought to bear in an attempt to limit upstream water use. As a result, water use must be assessed from a basin-wide perspective with specific emphasis on intersectoral competition among agricultural, urban, industrial, and environmental uses. Because WHI systems are invariably small and dispersed, they are often overlooked in basin-level water allocation agreements. However, as rising demand in the face of constant supply drives river basins increasingly toward "closure," there will no doubt be increasing attention paid to water

${ }^{4}$ River basin-level assessments of water use account for recycling and reuse, unlike system-level assessments, which view these as "losses". This approach is presented in greater depth by Seckler (1996) and Molden (1997). 
use and management in WHI systems, as is occurring in the Lerma-Chapala Basin in Mexico discussed below.

The central issue addressed in the paper is the impact of external economic and water resource policy changes on collective action in water scarce WHI systems, as demonstrated in the case of the Lerma-Chapala Basin in Mexico. Modification of Article 27 of the Mexican Constitution to allow sale and transfer of ejido land, combined with falling grain prices resulting from the implementation of the North American Free Trade Agreement (NAFTA), have fundamentally changed the basic conditions under which agriculture and water resources are managed in Mexico. Ejidos' collective management of land, water and other watershed resources will increasingly pass to private, individual hands. Further, competition for scarce water implies a larger set of basin-wide tradeoffs with bans being placed on new water harvesting impoundments and increased attention being paid to water management at the WHI system level. Such external factors will tend to move ejidos towards watershed resource use with higher productivity, particularly of irrigation water. Paradoxically, some of the very changes that challenge current collective resource management may provide the opportunities for the transition to higher productivity, specifically off- farm income flows and migrants' newly acquired farming expertise.

\section{WATER HARVESTING IN MEXICO: BACKGROUND AND OUTLOOK}

WHI systems (including storage and diversions) managed directly by farmers with limited external support account for over 14\% of Mexico's irrigated area (CNA 1998). Farmer-managed irrigation on average has higher agricultural productivity than 
do government-administered irrigation districts in Mexico (Palacios-Vélez 1997) although there is considerable variability by water source, crop type, land tenure, etc. Farmer-managed irrigation demonstrates high average productivity despite the policy and investment emphasis on the latter. In surface water harvesting systems in the LermaChapala Basin study area (see below), the cropping pattern is predominantly maize, sorghum, wheat, and barley for grain (with stover used as forage), and garbanzo.

The institutional arrangements devised by farmers and water users to manage the water captured in upland watersheds range from collective rules for access to common property centered on existing ejido ${ }^{5}$ organizations to private development and appropriation of watershed resources (Silva-Ochoa et al. 2000). Notable characteristics of water harvesting systems in Mexico are the low financial cost of water and their flexibility in adapting irrigation operation to users' needs, allowing for the pursuit of offfarm economic activities with important gender implications. Recent policy changes in Mexico aimed at restructuring collective resource ownership and agriculture in general coupled with increasing water competition pose significant challenges to the future sustainability of farmer-managed water harvesting systems. Nevertheless, common property management in Mexico in general, and WHI systems in specific, have shown considerable resilience to external forces in the past, and it is clear that the $y$ are in the process of adapting to the current set of pressures. A brief historical overview of water harvesting and irrigation in Mexico should demonstrate this adaptability.

5 Ejidos are agrarian communities in Mexico, established beginning in the 1930s, in which land and water resources are held as common property with private usufruct rights. 
There is considerable archaeological evidence (Tortolero-Villaseñor 2000) to suggest that runoff was captured, stored, diverted, and otherwise conveyed to irrigate settled agricultural land in the Teohuacán valley, for instance, not long after maize was first domesticated there between 5000 and 3500 B.C. (Hernández 1998). Additionally, filtration galleries (similar to the Middle Eastern qanats) were constructed to use groundwater. In both cases, the link between water and the watershed hinterlands that produced this resource was intrinsically recognized. ${ }^{6}$

Our purpose here is to show a pervasive and enduring reliance on water in Mexico, particularly for irrigation. The historical evidence suggests that residual moisture cultivation on seasonally receding lakebeds was practiced where salinity did not present a problem; however, local geological and hydrological conditions in the watersheds limited more widespread adoption of this practice. ${ }^{7}$ Water management innovations included river diversions and seasonal storage ponds (jagüeyes) around which human settlements formed. Additionally, the harvesting of ephemeral runoff flows generated in small watersheds during the rainy season and stored in earthen or masonry structures allowed for dry season irrigation. Little is known about the internal water allocation and distribution practices adopted for these small watershed water harvesting systems.

\footnotetext{
${ }^{6}$ The atl-tépetl (water-mountain) duality figured prominently in the cosmology of the Mexica and other Mesoamerican people.

7 The chinampas of Xochimilco in the Valley of Mexico present an innovative water management solution to cultivation in the shallow lakes. Organic matter dredged from canals was continually applied to the fields, raising their level above the lake and allowing adequate drainage and salt removal in addition to taking advantage of intensive nutrient recycling.
} 
While early Spanish colonization imposed new forms of surplus extraction and exploitation of irrigated agriculture, the relative isolation of small indigenous water harvesting systems permitted them to continue their own local practices. However, as mining gained importance and soon came to dominate the colonial economy, i.e., by the early $17^{\text {th }}$ Century, surplus food production again became an imperative. Indigenous water harvesting systems were supplanted, enlarged, or entirely redone with hybrid Spanish-Moorish ${ }^{8}$ irrigation technology. Many of the colonial systems located on prime agricultural land were abandoned with the advent of tubewell irrigation in the past several decades; however, this may reflect modern farmers' ignorance of their original function as residual moisture cultivation systems (Eling and Sánchez 2000) as opposed to the present preference for off-field storage and conveyance systems.

Indigenous and colonial water management followed fascinating and interlinked processes of development. Both were based on relatively small systems depending on seasonal runoff or river baseflow generated in upland areas of the watersheds in which they were located. The scale of these systems allowed for irrigation-watershed integration of resources and social relations, given that irrigation water users (whether in small rural communities or the large haciendas) were invariably the users of other watershed resources, including forest produce, timber, firewood, and importantly pasture and range for livestock (abrevaderos). Many of the smaller water harvesting systems in the upper watersheds, in fact, were expressly built to provide water for livestock.

8 The colonization of New Spain followed the Inquisition with the expulsion and voluntary migration of the Moors from the Iberian Peninsula, in many cases, to the colonies. Masonry stone work from this period in Mexico shows clear Islamic influence and the case has been made that construction practices and technologies also bear this influence (see Sánchez-Rodríguez 2000). 
In other cases, however, irrigation was reserved for the haciendas, with effective exclusion of campesinos, which were forced to rely on rainfed agriculture and livestock. As water use intensified in the lower watersheds, in contrast to extensive use of upper watershed resources, upstream-downstream conflicts became more pronounced. The Mexican Revolution, particularly the Zapatista current, was fought in response to expropriation of communal lands; however, hacienda control over land and water was not fully broken until Cárdenas' agrarian reforms of the 1930s and the establishment of the ejidos or land reform communities. These developments are important precursors of present day systems of communal management of watershed resources and warrant some additional discussion.

Land was titled to the ejido, the legal body of the entire community represented by a general assembly and elected leaders. Individual ejidatarios only held usufruct rights, although these tended to be stable and could be transferred among generations within the same family. Sale or transfer of usufruct outside the ejido was illegal, engendering strong community control over both agricultural land and extensive range for livestock. Water rights in Mexico are legally tied to land (Kloezen 1999)—directly in the case of surface water, and implicitly though less directly for groundwater. As a result, water management is inextricably linked to land tenure and decision-making.

The 1940s and 1950s saw the consolidation of ejido management of common property resources, including surface water harvesting systems in Mexico. At the same time, private interests were gaining increasing control over groundwater resources (Wester, et al. 1999), paralleling trends observed in other countries with important irrigation sectors (Shah 1993). The benefits of private and public investment in 
groundwater development have been disproportionately captured by private interests, while 'traditional' irrigation systems (including large surface storage dams, but also importantly for the analyses presented in this paper, the small water harvesting systems) are more the purview of the ejido sector (Palerm-Viqueira 2000). While there is still significant participation of private interests in the large public irrigation districts, WHI systems are predominantly managed by ejido users, with limited government support or intervention.

Small user-managed irrigation in Mexico consists of individual unidades de riego (irrigation units or systems, subsequently referred to as unidades in this article), each with its own water source, internal set of water allocation and distribution rules, and water users organization (structured or informal). Water users organize themselves to carry out basic internal WHI activities-watershed management, water capture, allocation, and distribution—and to handle external representation with government programs and exogenous demands (either competing or complementary) for water and other resources.

Two defining and interrelated characteristics of the unidades are the equity of access to irrigation and the low costs of water (in financial, but not necessarily labor, terms). Equitable water allocation stems from the communal management of resources implicit in the ejido model of agrarian organization. The low financial cost of water in WHI systems is a product of simple technologies using local expertise and materials. There is rarely, if ever, provision made for contingencies or regular maintenance of infrastructure. As a result, special effort is required to mobilize labor and financial 
resources for repairs when systems break down. The capacity of communities to come together for ongoing activities as well as crises determines the sustainability of WHI.

The degree to which local organization is formalized is often dictated by the complexity of internal water management tasks (Dayton-Johnson 1999) and by the need for liaison with external parties, particularly where conflict threatens access to water as will be shown in one of the cases studied. Community organizations for WHI management may either be based on existing community decision- making structures, or develop separately from them, with implications for their effectiveness in managing processes internal and external to the WHI system. We contend that the effectiveness of WHI orga nizations — formal or informal—in carrying out water management objectives depends on how able they are to focus on specific, internal water management tasks. External representation, however, may be handled equally effectively when combined with a larger set of community objectives.

Article 27 of the Mexican Constitution was amended in 1992 permitting titling and subsequent sale of ejido land, ostensibly to provide ejidatarios with the same competitive advantage as the private farmers in terms of access to credit and investment. Market forces, however, have rapidly eroded a functioning if somewhat sheltered communal resource management system, exposing it to a wider set of competitive processes under the North American Free Trade Agreement (NAFTA). The adaptive response of ejidos has been mixed (Snyder 1999; De Janvry et al. 1997) in terms of their ability to diversify and intensify production in the face of the NAFTA challenge. Falling prices of basic grains (maize, sorghum, and wheat) because of cheap imports from the U.S. and Canada have reduced ejido farmers' returns - although prices for the preferred 
local maize for tortillas have not fallen proportionally—and increased the need for crop diversification. At the same time, vegetable production is highly risky for newcomers, both as a result of agronomic factors, pest control, etc. as well as marketing challenges. Few ejidos have diversified production successfully, although increasing numbers of individual ejidatarios are entering contract-farming arrangements (with their own share of risks). The structural changes brought about under NAFTA and the response of Mexican farmers—-both ejidos and others—-will have profound impacts on land and water resource management in the coming years.

Irrigated agriculture is one of multiple rural livelihood strategies in the ejidos, where labor is the household resource whose allocation must be optimized (Buechler forthcoming). As a result, irrigation is rarely allocated a significant share of household financial resources. Further, the periodic resource mobilization required in WHI systems, for instance to reconstruct damaged diversions or canals, increases the labor costs for access to water. Where farmers have access to off-farm income sources, including considerable male seasonal or permanent migration, WHI systems have had to evolve flexible water distribution practices. In spite of gendered migration in Mexico with young men seeking employment in the United States in significantly greater numbers than women, existing ejido management of water has tended to exclude women from formal decision-making (Buechler 2000). Significant numbers of women are water users, and WHI in this context calls for strategies that afford women greater access to irrigation. The flexibility of irrigation operations, including the ability to trade or rent turns, is important if women are to gain more access to WHI management. 
The remainder of this paper looks at the strategies of two systems for managing the resources and maintaining the necessary collective action. While both are in a closed basin with competition for water, Trojes de Paul has more storage capacity and irrigated area per user, but fewer alternative livelihood options, while Nápoles faces more external competition for water but more alternative sources of income, so that irrigated production is less important to ejido households.

\section{LERMA-CHAPALA BASIN WATER COMPETITION}

The Lerma-Chapala basin in Mexico (see Figure 1) has total consumptive water demands that significantly exceed average water supply (de Anda et al. 1998). The $55,511 \mathrm{~km}^{2}$ basin (including two adjacent closed basins) covers five states and is the source of water for 15 million people (11 million within the basin, and 2 million each in Mexico City and Guadalajara). The Lerma River rises on the slopes of the Toluca volcano and flows over $500 \mathrm{~km}$ through forest, rich farmland, urban areas, and semi-arid scrubland before emptying into Lake Chapala, Mexico's largest freshwater lake. When storage volumes in the lake permit, controlled outflows are passed to the Santiago River that empties in the Pacific Ocean. 
Figure 1. Lerma-Chapala Basin

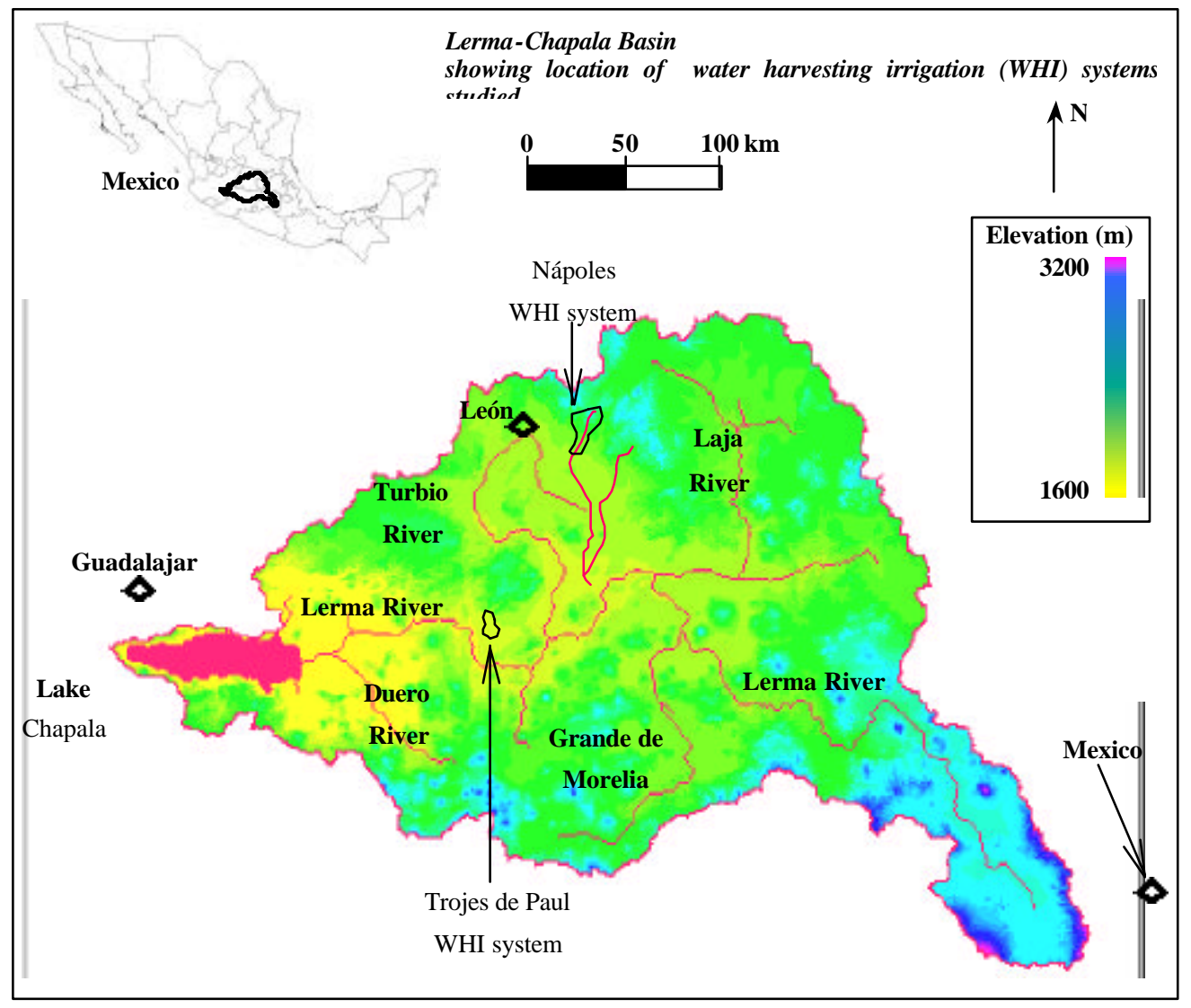

Surface and groundwater resources in the Lerma-Chapala basin are subject to rampant competition and rapid depletion, and water quality is a major concern. Lake Chapala, the receiving waters of the basin, reflects the cumulative impacts of upstream activities (natural and anthropogenic) and serves as an indicator of the sustainability of water resources development. The irrigated area in the basin grew from around 200,000 ha in the 1950s to 800,000 ha in the 1980s (Wester et al. 1999), which coupled with a declining trend in rainfall, has resulted in decreased Lerma River inflows to the lake and dramatic decreases in the volume stored. Two low storage periods (in the mid-1950s and 
1999-2000) characterize the lake's behavior since 1934 when systematic data collection began-. Average inflows of the Lerma River were significantly higher in the 1950s than they are now (de Anda 1998) and the lake recuperated to full storage in 1959. Given the present over-exploitation of groundwater throughout the basin and the development of surface water in the upper sub-basins, it is unlikely that the lake will recover without exceptional runoff as generated through a major hurricane.

In 1989 the federal government and the governments of the five states in the basin signed an historic agreement that adopted four main objectives to improve water resources management in the basin:

1. control and regulate surface water use and distribute water fairly among users

2. improve water quality

3. increase water-use efficiency

4. conserve the river basin ecosystem

In pursuit of the first objective, a surface water allocation agreement was signed in August 1991 that banned further development of water harvesting in an attempt to increase runoff flows to the lake. Nevertheless, the installed capacity of minor water storage systems not inventoried by basin authorities (CNA 1999) accounts for 27\% of all constructed surface water storage volume, not including lakes (Scott and Flores-López, manuscript in preparation). Remote sensing imagery from the Oct.-Nov. 1998 period when surface storage systems were full, coupled with digital terrain analysis, indicated that minor storage exceeds 700 million $\mathrm{m}^{3}$ (MCM). A total of 28,895 water harvesting reservoirs each smaller than 2.5 MCM (the threshold definition for large reservoirs) hold a combined $314 \mathrm{MCM}$, or $11 \%$ of the constructed storage in the basin. Clearly, a 
significant number of the medium-sized reservoirs do not appear in the inventory. Although the smallest water harvesting systems are for livestock rather than irrigation, there are nevertheless over 800 small reservoirs each capable of irrigating at least 5 ha of land. The total irrigable area under these WHI systems is 34,000 ha, assuming typical cropping patterns under irrigation efficiencies of 50\%. Thus the impact of WHI systems on the Lerma-Chapala basin water balance is considerable. Basin authorities have expressed interest and concern over the preliminary results presented above.

\section{FIELD STUDIES OF WATER HARVESTING IRRIGATION}

As part of a larger effort to understand the relationship between farmer-managed irrigation and the management of the Lerma-Chapala Basin, field research was undertaken in 25 unidades with eight developed as detailed case studies covering a range of social, institutional and water resources issues (Silva-Ochoa et al. 2000). For this paper, we present and analyze field data on the only two systems among the eight that rely on surface water harvesting — Trojes de Paul and Nápoles (see Figure 1). These systems were selected as representative of WHI systems in the Lerma-Chapala Basin and have comparable numbers of users, irrigable land and cropping patterns. Given the difference in water availability between the two, we expected that water allocation would differ. Further, their location relative to urban employment opportunities suggested some differences in livelihood strategies. However, similar levels and type of collective action around WHI and other watershed resources were expected in both systems, given the need to keep the systems functioning in the face of external changes. It should be noted that since the field study was completed, land in both ejidos has been titled to the 
respective ejidatario (or ejidataria) operators. ${ }^{9}$ The general characteristics of the two

WHI systems studied are presented in Table 1.

Table 1. Characteristics of Water Harvesting Irrigation Systems Studied

\begin{tabular}{lcc}
\hline & Trojes de Paul & Nápoles \\
\hline Number of water users & 53 & 51 \\
Women water users (\#, \%) & $9(17 \%)$ & $10(20 \%)$ \\
Estimated watershed area (ha) & 3,000 & 10,000 \\
Water harvesting type & $\begin{array}{c}\text { On-stream storage for } \\
\text { single community }\end{array}$ & $\begin{array}{c}\text { Run-of-river diversion with } \\
\text { inter-community allocation } \\
\text { and off-stream storage }\end{array}$ \\
Estimated reservoir volume $\left(\mathrm{m}^{3}\right)$ & $1,300,000$ & 50,000 \\
Irrigable area (ha) & 142 & 105 \\
Irrigable area per user (ha/user) & 2.7 & 2.1 \\
Avg. annual rainfall (mm) & 630 & 600 \\
Avg. annual pan evap. (mm) & 1,860 & 1,780 \\
Cropping pattern & Sorghum, maize (summer) & Maize, sorghum (summer) \\
& Wheat, barley (winter) & Wheat, rarely, if water \\
& & permits \\
\hline
\end{tabular}

Trojes de Paul is the largest water harvesting system in the watershed it shares with El Sauz and El Colorado WHI systems (Figure 2). The Trojes reservoir has significantly greater storage capacity (per ha irrigated and per user) than Nápoles (see Table 1). As a result, from the users' perspective, this system is less water scarce than Nápoles and permits a higher degree of flexibility in irrigation distribution and operation. The reservoir was constructed in 1968 with considerable community resource

9 Except for minor inconsistencies in parcel boundaries in Trojes de Paul, land in both ejidos has been titled (Ing. José Ramírez, Registro Agrario Nacional, Guanajuato office, August 27, 2001, personal communication) through PROCEDE, or Programa de Certificación de Derechos Ejidales y Titulación de Solares (Program for Certification of Ejido Rights and Homestead Titling). PROCEDE began in late 1992 and by August 2001 had certified and titled 74\% of ejidos nationwide. Certification involves cadastral survey, review of land claims, a public assembly to delimit and assign lands, inscription in the National Agrarian Registry, and finally issuing certification and titles. 
mobilization and external representation to secure government support. In a clear indication of ownership of their community asset, Trojes residents took exception to the government's inauguration ceremony and placing of an official plaque at the reservoir. As a community, Trojes has access to two ejido tubewells, which in cases of extreme water scarcity may be used, through special agreement and payment, to complement surface water supplies. The present study focuses exclusively on the irrigation area and users whose only source of water is the surface reservoir.

Figure 2. Trojes de Paul Watershed and Irrigation Schematic Layout

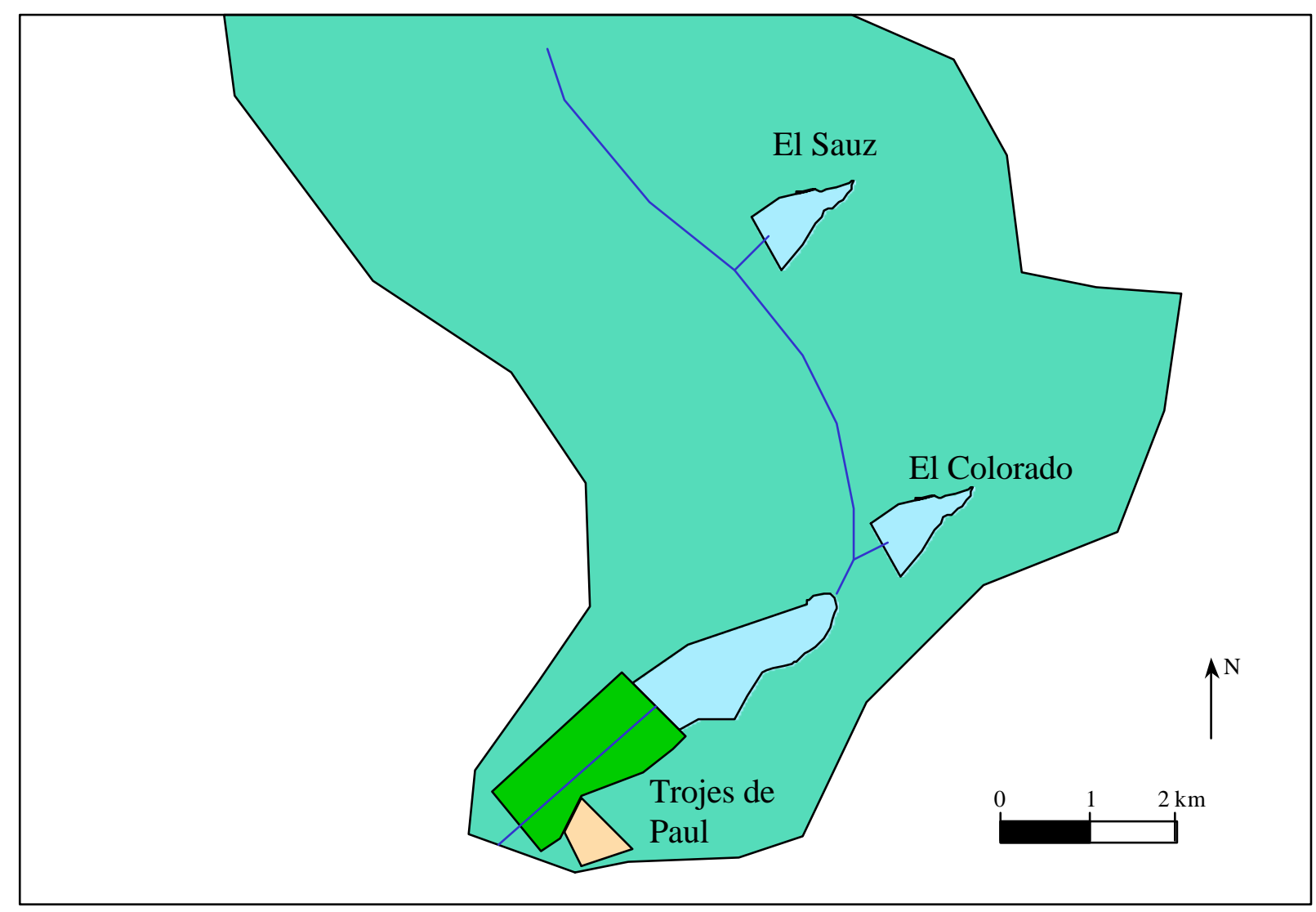


The Trojes water users group is organized somewhat more formally and distinctly from the ejido than in Nápoles, although a former ejido president serves as the head. Water management issues are determined separately from the regular ejido meetings, and cover a range of decisions related to labor mobilization to clear the canals, the start of irrigation, and distribution schedule (including changes in operation on a seasonal basis to allow tail- and head-end irrigators to alternate first access to water). Users show a degree of internal cohesion not evident in Nápoles, as demonstrated by their discussion of irrigation service fees to be paid to the users group (although these have not yet been accepted), as well as fines and sanctions for over-irrigating (when excess water drains off the ends of their fields). It is evident that the internal organization of water users in Trojes, coupled with higher water availability, allows this WHI to pursue an irrigation strategy that is risk averse and comparatively productive.

Nápoles, like Trojes, is an ejido-based WHI system. By contrast, however, Nápoles is located within 40 minutes commuting distance by public transport from the city of León and 20 minutes from the smaller town of Silao. Several factories pick up and drop off workers in trucks every day. Residents engage in diverse livelihood strategies, including off-farm employment and diversified activities within farming.

Water allocation rules in Nápoles are shaped by a combination of factors including conflict over water with a private landowner, and off-farm income opportunities, both of which contribute to Nápoles' all-or-nothing water allocation policy. Water from the adjacent Silao River is diverted by means of a semi-permane nt diversion structure into an earthen storage reservoir (Figure 3), which dates from the hacienda 
period. At least two additional water harvesting systems are located in the shared watershed, and agreements have been devised for inter-community water allocation. Interviews with local informants indicate that, given its upstream location, Comanjilla ejido has the right to fill its reservoir first, but that additional runoff is invariably available from this large mountainous watershed during the rainy season.

Figure 3. Nápoles Watershed and Irrigation Schematic Layout




Subsequently, the Nápoles water diversion structure takes water from the river down a right-bank canal. This is proportionally divided between Providencia de Nápoles ejido and a shared canal that feeds both Nápoles ejido and the private landowner who is a descendent of the hacendado whose land was distributed to these two ejidos in the agrarian reforms. Water concessions allocate a share of the water to the landowner whose small reservoir is just downstream of the ejido reservoir. In fact, the two had been part of a single, larger reservoir, but were divided by a new embankment with the ejido part located upstream. It appears that the relatively small size of all of the three storage structures ${ }^{10}$ in relation to the watershed would allow these to be filled in most years; however, resource mobilization of the labor, materials and capital required for the reconstruction of the diversion structure is the flash point.

During the 1999 study period, Nápoles refused to pass water to the landowner from their upstream reservoir, alleging that he had not contributed to the past year's diversion reconstruction effort. On one of our first visits to start the research for this project, Nápoles residents questioned whether we were government officials sent to collect information that would resolve the dispute. Cautious to observe this process from a distance, we were able to gain important insights into the ways in which conflict over water shaped community decision-making over water allocation.

Both the ejidatarios and the private landowner have attempted to access other sources of water, particularly groundwater; however, the availability of groundwater for conjunctive use is limited by an existing state-level ban on drilling new wells, with only one existing tubewell and one shallow well used by individuals and not available to other

\footnotetext{
${ }^{10}$ Providencia has no storage, but is simply free flow irrigation from the diversion structure.
} 
water users. As a result, surface water is in significant demand. While acutely aware of the ban on new wells, users in both Nápoles and Trojes had not heard of the ban on new water harvesting systems resulting from the 1991 Lerma-Chapala surface water agreement.

Partly in response to external claims over water, irrigation decision-making in Nápoles is intimately linked with the ejido structure. Decisions on who will serve as water arbiters (jueces de agua), water use, labor mobilization and external relations are made by consensus, normally during the course of regular ejido meetings. Separate meetings of water users to discuss water management issues may be called; however, given the relatively small size of the users group and a high degree of absentia from the community in general (due to migration and urban employment), decisions related to irrigation tend to be made informally. On at least one occasion, the ejido president negotiated and received from the Silao municipal authorities construction materials intended for housing improvement, but ultimately used to repair the WHI infrastructure. Disaster relief for the summer 1999 season described below was never received in Nápoles even though these funds were available from state and federal programs, because of opposing political parties at the ejido and municipal levels. These are examples of WHI issues being incorporated into or influenced by ejido management and politics.

\section{CONTRASTING STRATEGIES FOR COLLECTIVE ACTION}

In Trojes, water is allocated by landholding area in the command area with individual users determining when to complete irrigating their fields and pass water on to the next user. All users accept equity of distribution based on land holding, if not 
equality of distribution to all members, and minimal infighting was detected. Table 2 presents the data on water allocations and actual deliveries for the two systems.

Trojes allocated water per unit land, not per user. The system had water stored from the 1998 rains and applied its summer irrigation to sorghum at planting time (an option not available to Nápoles whose reservoir was dry) based on land area. By contrast, irrigation water in Nápoles is allocated based on four-hour rotational turns, irrespective of flow (which does vary depending on the reservoir level) or of the ejidatarios' parcel size. In the 1999 summer season studied, each water user applied the fixed share of water to whatever area he or she deemed appropriate. In the following winter season, Nápoles had no water remaining (with the reservoir now serving as the football field) and was unable to irrigate, while Trojes users were able to irrigate wheat on four separate occasions and obtain good yields of 6 ton/ha on average.

In a Nápoles ejido meeting based on consensus decision- making, water users decided to irrigate their maize and sorghum to supplement rainfall in September 1999. Nominally, each user was to irrigate 0.5 ha of her or his larger rainfed parcel, although all agreed that the actual area would depend on parcellevel water management. From the exceedingly low irrigation depths applied (see Table 2), it is apparent that users anticipated additional rain. However, rainfall in 1999 was critically low (a total of 411 $\mathrm{mm}$, or $32 \%$ lower than average) with the result that the entire grain crop was lost. Although stover was used as fodder, it is estimated that its financial value (i.e., shadow price as estimated by replacement value) was lower than the anticipated grain value by a factor of ten. Such crop failures are not uncommon in Nápoles, with no grain harvest reported for two of the past five years. 
Comparison of the measured data for both systems in Table 2 confirms that the strategy articulated by each WHI was followed, with Trojes showing zero variation in land area irrigated as a portion of total holding in the command area and Nápoles showing zero variation in the duration of irrigation turns. In Nápoles, a total of eight users sold their turns (at US\$2.63 per hour or US\$10.50 per 4-hour turn, although prices were negotiated based on the actual storage in the reservoir under the recognition that flow varied). Additionally, there was significant trading of turns to accommodate offfarm labor demands, particularly by women. 
Table 2--Water Allocation and Deliveries in Trojes and Nápoles

\begin{tabular}{|c|c|c|c|c|c|}
\hline & $\begin{array}{ll}1 & \text { Trojes }\end{array}$ & & & & 2 Nápoles \\
\hline & $\begin{array}{c}\text { Measured }(\mathrm{n}=9) \\
\mathrm{A}\end{array}$ & $\begin{array}{c}\text { Reported }(\mathrm{n}=53) \\
\text { B }\end{array}$ & $\begin{array}{c}\text { Measured }(n=5) \\
C\end{array}$ & $\begin{array}{c}\text { Reported }(\mathrm{n}=51) \\
\text { D }\end{array}$ & $\begin{array}{c}\text { Nominal }(\mathrm{n}=51) \\
\mathrm{E}\end{array}$ \\
\hline \multicolumn{6}{|c|}{ Irrig. Duration (hrs/turn) } \\
\hline - Average & 36.7 & 36.4 & 4 & 4 & 4 \\
\hline - St. deviation & 16.9 & 7.1 & 0 & 0 & 0 \\
\hline - Coeff. Variation & 0.46 & 0.20 & 0 & 0 & 0 \\
\hline \multicolumn{6}{|l|}{ Land irrigated/total } \\
\hline - Average & 1 & 1 & 0.60 & 0.55 & 0.27 \\
\hline - St. deviation & 0 & 0 & 0.42 & 0.28 & 0.14 \\
\hline - Coeff. Variation & 0 & 0 & 0.70 & 0.50 & 0.52 \\
\hline \multicolumn{6}{|l|}{ Land irrigated (ha) } \\
\hline - Average & 2.0 & 2.7 & 1.7 & 1.0 & 0.5 \\
\hline - St. deviation & 0.2 & 2.2 & 1.5 & 0.3 & 0 \\
\hline - Coeff. Variation & 0.09 & 0.82 & 0.87 & 0.29 & 0 \\
\hline \multicolumn{6}{|c|}{ Irrigation depth/turn (mm) } \\
\hline - Average & 205 & 206 & 72 & 72 & 156 \\
\hline - St. deviation & 44.5 & 21 & 26 & 8 & 0 \\
\hline - Coeff. Variation & 0.22 & 0.10 & 0.36 & 0.12 & 0 \\
\hline \multicolumn{6}{|l|}{$\underline{\text { Total number of turns }}$} \\
\hline - Average & 4 & 4 & 1 & 1 & 1 \\
\hline - St. deviation & 0 & 0 & 0 & 0 & 0 \\
\hline - Coeff. Variation & 0 & 0 & 0 & 0 & 0 \\
\hline
\end{tabular}

Note: Measurements of flow, duration and area were made at the parcel level for a limited number of irrigations (columns A and C; sample size indicated). Reported depth, duration and area (columns $\mathrm{B}$ and $\mathrm{D}$ ) included all users based on interviews of duration and area, combined with average flow. Nominal data for Nápoles (column E) are those that would have resulted from the nominally agreed area of 0.5 ha per 4hour turn.

Strictly speaking, appropriation of land and water resources was not equitable in either system with high variations in area irrigated and irrigation depths applied. In Trojes the variation in land irrigated was the result of differences in landholding in the command area, while for Nápoles, the extremely high variation in measured irrigated area $(\mathrm{CV}=0.87)$ reflects differences in parcel-level water management. Notwithstanding the skewed landholding size in the irrigation command area in Trojes, the irrigation depth based on reported turns demonstrated low variation $(\mathrm{CV}=0.10)$ suggesting that water deliveries in Trojes follow the area-based water allocation rules quite closely. Trojes was 
able to provide four satisfactory irrigations and users obtained good yields. By contrast, the low irrigation depth applied in Nápoles was insufficient to provide for crop water requirements in the face of deficient rainfall, which coupled with early frosts and low sorghum prices, left farmers with no option but to abandon their crop as the income would not have covered harvesting costs.

Nápoles faced acute scarcity and followed a high-risk rainfall supplement strategy of distributing limited irrigation to all users with the result that all grain production was lost. The relatively high productivity attained in Trojes appears to result from a better match between water available and land irrigated, although this was not distributed equally among all users. Table 3 based on our field data presents productivity indicators for the two systems.

\section{Table 3--Productivity Indicators}

\begin{tabular}{|c|c|c|c|c|}
\hline \multirow[b]{2}{*}{ Indicator } & \multicolumn{2}{|c|}{ Summer 1999} & \multicolumn{2}{|c|}{ Winter 1999-2000 } \\
\hline & Trojes & Nápoles & Trojes & Nápoles \\
\hline Relative water supply (RWS) & 1.4 & 0.8 & 1.7 & no irrigation \\
\hline Relative irrigation supply (RIS) & 0.5 & 0.2 & 1.7 & \\
\hline $\begin{array}{l}\text { Gross value of grain production by } \\
\text { area }(\mathrm{GVP} / \mathrm{ha} \text {, in } 1999 \mathrm{US} \$)\end{array}$ & 740 & $\begin{array}{c}0 \\
\text { (grain crop } \\
\text { lost) }\end{array}$ & 920 & \\
\hline $\begin{array}{l}\text { Gross value of grain production by } \\
\text { water }\left(\mathrm{GVP} / \mathrm{m}^{3} \text { in } 1999 \text { US\$) }\right.\end{array}$ & 0.30 & & 0.09 & \\
\hline $\begin{array}{l}\text { Water productivity, "crop per drop" } \\
\left(\mathrm{kg} \text { grain } / \mathrm{m}^{3}\right)\end{array}$ & $\begin{array}{c}1.4 \\
\text { (sorghum) }\end{array}$ & & $\begin{array}{c}1.0 \\
\text { (wheat) }\end{array}$ & \\
\hline $\begin{array}{l}\text { For discussion of productivity ind } \\
\text { RWS = (rainfall + irrigation) / cro } \\
\text { RIS = irrigation / crop evapotrans } \\
\text { GVP = yield (tons/ha) * farmgate } \\
\text { GVP/m } \mathrm{m}^{3} \text { uses irrigation applied } \\
\text { Water Productivity uses volume o }\end{array}$ & $\begin{array}{l}\text { ors, see Molde } \\
\text { apotranspirati } \\
\text { ive demand } \\
\text { e (Mex\$/ton, a }\end{array}$ & $\begin{array}{l}\text { et al. (1998). } \\
\text { US } \$ 1=\text { Mex } \$ 9 \\
\text { (demand) }\end{array}$ & $\begin{array}{l}\text { efly, } \\
\text { AO, 1996) }\end{array}$ & \\
\hline
\end{tabular}

Relative water supply (RWS) and relative irrigation supply (RIS) are explanatory variables as opposed to performance indicators. If the basic crop water requirement is 
not met (RWS $<1$ ), yield can be expected to decrease. RIS simply indicates the portion of crop demand met by irrigation with the difference attributable to rainfall, e.g., summer 1999. Gross value of production (GVP) by area or water provides a measure of output (grain) received per unit of resource utilized. Rainfall supplemental irrigation invariably shows high $\mathrm{GVP} / \mathrm{m}^{3}$ and should be interpreted with caution, as the entire production cannot be attributed to irrigation. The "crop per drop" water productivity is calculated using the volume of water consumed in evapotranspiration, as it is difficult to estimate the volume of water used beneficially by the crop vs. that "lost" to drainage or percolation. The GVP/ha and $\mathrm{GVP} / \mathrm{m}^{3}$ results for Trojes compare very favorably with other small farmer-managed irrigation systems and the larger irrigation districts in the study area (Silva-Ochoa et al. 2000), while the "crop per drop" results indicate good physical productivity compared with data for similar grains from around the world (Molden et al. 1998).

The relatively high productivity of Trojes must be understood in the context of social relations, both internal and external to the water users group. The water harvesting reservoir was constructed as recently as 1968 , with significant community participation in terms of labor and materials. External support for the reservoir was negotiated and secured from the agriculture and water resources ministry (Secretaría de Agricultura y Recursos Hidráulicos, SARH, 1991) through the efforts of influential community members. This combination of community organization and concerted representational effort allowed for the consolidation of a water users organization separate from the ejido. Given the smaller size of this watershed than Nápoles and the fact that the terrain is more accessible, Trojes residents have contacts with other communities in their 
catchment (Las Tinajas, Sauz de Villaseñor, and Colorado de Saavedra). However, intercommunity rules are not articulated for common property management of grazing and forest resources. Nevertheless, Trojes users are acutely aware of catchment deterioration resulting in the sedimentation of their reservoir. Initiatives, unsuccessful so far, have been made by Trojes water users to secure government support for sediment removal from the reservoir. From a preventive perspective, however, Trojes would likely benefit from including forest and grazing resources in a more integrated management body. Given the successful functioning of the irrigation users group, based on rules and accepted water allocations practices, Trojes appears to be ready to expand collective action initiatives to include these other resources, particularly to safeguard the reservoir.

At one level of analysis, the strategy of spreading water equally among irrigation users in Nápoles resulted in the loss of all grain production. However, when viewed in the context of the ejido facing a set of external challenges to their water source, this strategy has a different interpretation. Tensions have existed with the private landowner since the creation of the ejido, resulting in the division of the reservoir. Informants told us that in 1996, their reservoir was emptied when community members were away on pilgrimage, with the allegation that the embankment broke, filling the landowner's reservoir. This level of resource competition requires community solidarity as has been achieved through strict adherence to equal water access for all users.

Furthermore, labor contribution for the periodic reconstruction of the diversion is critical to the continued viability of Nápoles' access to water, and must be mobilized in a situation where peri-urban employment alternatives significantly increase the opportunity costs of labor. Water users clearly recognize that irrigation can only be supplemental to 
rainfed crop production, which as an income generating activity, is in turn supplemental to off-farm employment. As a result, WHI in Nápoles is significantly more residual as an economic activity than in Trojes (which is both less water scarce, but also importantly, has fewer off-farm opportunities than Nápoles).

\section{CONCLUSIONS}

Recent economic and water resources policy changes in Mexico will have important consequences for collective action and common property management of small surface water harvesting irrigation systems that have historically been held in communal ejido tenure. Neo-liberal economic reforms have resulted in privatization of land-based resources including water, while the signing of the North American Free Trade Agreement has seen prices for basic grains fall. Additionally, increasing water scarcity and competition at the watershed and river basin levels places further pressure on traditional water management and allocation systems. In the two case studies presented, contrasting responses at the community level were apparent. In the first, more conventional WHI system, water management decision- making distinct from the ejido structure combined with relative water abundance allowed high water productivity. Consolidation of the water users group also appeared to raise the possibility of taking on additional (collective) watershed management tasks, including erosion and sedimentation issues. In the second, more water scarce system, WHI was subsumed under a broader set of community goals in which sharing water among all members of a group was an important means to ensure solidarity. 
The residual nature of subsistence farming in the context of growing off-farm employment opportunities, particularly in the second community, results in low levels of labor and capital allocation and increased risk for crop production; in essence, this implies that WHI is supplemental to rainfed agriculture, which in turn is supplemental to wider household economic strategies. In the context of migration and the attendant feminization of smallholder agriculture in Mexico, WHI must provide optimal flexibility in order to receive sufficient allocation of the household labor resources required for its continued viability. This consideration is apparent to the actual WHI users, many of whom are women; however, government intervention to support WHI must bear this in mind. So far, the WHI systems studied have continued to receive low but sustaining levels of household labor and financial resources. Despite increased urban and nonagricultural activity, keeping a foot in agriculture is an important form of income diversification, to hedge against the risks involved in other economic activities. Maintaining the sense of community may be an even more important source of livelihood security; hence the emphasis on working through the ejido organization.

At the river basin level, WHI systems use water that may have more productive uses downstream, particularly when considered from an intersectoral perspective of competition among agriculture, urban, industrial and environmental demands for water. In water-short basins such as the Lerma-Chapala Basin, there is likely to be increased attention paid to water use by small WHI systems in upstream catchments. WHI will need to increase the productivity of water in order to continue to receive basin-level allocations. A number of alternatives appear to make sense, particularly crop diversification. Several of the external changes discussed may well provide the means to 
increase water productivity, including off-farm income as a source of investment and expertise gained by migrants working in agriculture in the United States.

Given the resilience that WHI systems have demonstrated in their evolution, it is likely that they will adapt to the current set of pressures. However, the significant challenges posed by falling crop prices, increased dependence on off-farm income sources, increased interest on the part of basin authorities in WHI water use, and growing water scarcity indicate that WHI will remain a subsistence activity. As a result, ensuring productive and equitable benefits to users is critical for their continued viability. 


\section{REFERENCES}

Agarwal, Anil and Sunita Narain, ed. 1997. Dying wisdom: Rise, fall and potential of India's traditional water harvesting systems. New Delhi, India: Centre for Science and Environment.

Baland, Jean-Marie and Jean-Philippe Platteau. 1996. Halting degradation of natural resources: Is there a role for rural communities? Oxford: Clarendon Press.

Buechler, Stephanie J. Irrigated agriculture on Mexican ejidos: Complementarities with off- farm economic strategies. In Managing a sacred gift: Water management strategies in Mexico, ed. Scott Whiteford and Roberto Melville. San Diego, USA: Center for U.S.-Mexican Studies, University of California. Forthcoming.

Buechler, Stephanie J. 2000. El trabajo de las mujeres, niños, niñas y hombres en parcelas irrigadas de Guanajuato en épocas de crísis. In Anduve detrás de todo a la corre y corre... Género y manejo del agua y tierra en comunidades rurales de México, ed. Buechler, Stephanie and Emma Zapata-Martelo. IWMI Serie Latinoamericana 14. Mexico City, Mexico, and Colombo, Sri Lanka: International Water Management Institute.

CNA (Comisión Nacional del Agua). 1999. Diagnóstico regional. Proyecto lineamientos estratégicos para el desarrollo hidráulico de la Región Lerma-Santiago-Pacífico. Comisión Nacional del Agua (CNA). Gerencia Regional Lerma-SantiagoPacífico. Guadalajara, Mexico: CNA.

CNA (Comisión Nacional del Agua). 1998. Diagnóstico Preliminar sobre Superficies Regables y Volúmenes Requeridos en las Unidades de Riego Organizadas y Sin Organizar. Comisión Nacional del Agua (CNA) and Colegio de Postgraduados (CP). Montecillo, Mexico: CNA and CP.

Dayton-Johnson, Jeff. 1999. Irrigation organization in Mexican unidades de riego: Results of a field study. Irrigation and Drainage Systems. 13(1): 55-74.

De Anda, J., S.E. Quiñones Cisneros, R.H. French, and M. Guzmán. 1998. Hydrologic balance of Lake Chapala (Mexico). Journal of the American Water Resources Association. 34(6): 1319-1331.

De Janvry, Alain, Gustavo Gordillo, and Elisabeth Sadoulet. 1997. Mexico's second agrarian reform: Household and community responses, 1990-1994. San Diego, USA: Center for U.S. Mexican Studies, University of California.

Eling, Herbert H. and Martín Sánchez-Rodríguez. 2000. Presas, canales y cajas de agua: la tecnología hidráulica en El Bajío mexicano. In Antología sobre Pequeño Riego. 
Vol. II. Organizaciones Autogestivas, eds. Jacinta Palerm-Viqueira and Tomás Martínez-Saldaña. Montecillo, Mexico: Colegio de Postgraduados.

FAO (Food and Agriculture Organization). 1996. Crop Water Requirement (CROPWAT) software. Rome, Italy: Food and Agriculture Organization.

Hernández, Raúl. 1998. Agua para siempre: obtención de agua y conservación de suelos a través de la regeneración de cuencas. XX Coloquio de Antropología e Historia Regionales. Agua, Medio Ambiente y Desarrollo en México, pp. 78-89. Zamora, Mexico: Colegio de Michoacán, October.

Kloezen, Wim H. 1999. Water markets between Mexican water user associations. Water Policy 4: 437-455.

Merrey, Douglas J. 1997. Expanding the frontiers of irrigation management research. Results of research and development at the International Irrigation Management Institute, 1984 to 1995. Colombo, Sri Lanka: International Irrigation Management Institute.

Molden, David J. 1997. Accounting for water use and productivity. SWIM Paper 1. Colombo, Sri Lanka: International Irrigation Management Institute.

Molden, David J., R. Sakthivadivel, Christopher J. Perry, Charlotte de Fraiture, and Wim H. Kloezen. 1998. Indicators for comparing performance of irrigated agricultural systems. Research Report 20. Colombo, Sri Lanka: International Water Management Institute.

Ostrom, E. 1992. Crafting institutions for self-governing irrigation systems. San Francisco, CA, US: Institute for Contemporary Studies Press.

Oweis, Theib, Ahmed Hachum and Jacob Kijne. 1999. Water harvesting and supplemental irrigation for improved water use efficiency in dry areas. SWIM Report 7. Colombo, Sri Lanka: International Water Management Institute.

Palacios-Vélez, Enrique. 1997. Las unidades de riego o pequeña irrigación. In Antología sobre Pequeño Riego. Vol. I, ed. Tomás Martínez-Saldaña and Jacinta PalermViqueira. Montecillo, Mexico: Colegio de Postgraduados.

Palerm-Viqueira, Jacinta. 2000. Organización social y agricultura de riego. In Antología sobre Pequeño Riego. Vol. II. Organizaciones Autogestivas, ed. Jacinta PalermViqueira and Tomás Martínez-Saldaña. Montecillo, Mexico: Colegio de Postgraduados.

Place, Frank and Brent Swallow. 2000. Assessing the relationships between property rights and technology adoption in smallholder agriculture: A review of issues and 
empirical methods. CAPRi Working Paper No. 2. Washington DC: International Food Policy Research Institute.

Sánchez-Rodríguez, Martín. 2000. De la autonomía a la subordinación: riego, organización social y administración de recursos hidráulicos en la cuenca del Laja, Guanajuato. Zamora, Mexico: El Colegio de Michoacán (mimeo).

SARH. 1991. Secretaría de Agricultura y Recursos Hidráulicos (SARH). Delegación en el Estado de Guanajuato. Programa de Control y Supervisión de la Operación. Coordinación de Enlaces de Ingeniería Agrícola. Celaya, Mexico: SARH (unpublished data).

Scott, Christopher A. 1994. Facing environmental degradation in the Aravalli Hills, India. In Environmental change in drylands: Biogeographical and geomorphological perspectives, ed. A.C. Millington and K. Pye. Chichester, UK: Wiley.

Scott, Christopher A. and Francisco J. Flores-López. The 'bordería' water harvesting system: Evaporation and infiltration tradeoffs at a watershed scale. (manuscript in preparation).

Seckler, D. 1996. The new era of water resources management. Research Report 1. Colombo, Sri Lanka: International Irrigation Management Institute.

Shah, Tushaar. 1993. Groundwater markets and irrigation development: Political economy and practical policy. New Delhi, India: Oxford University Press.

Silva-Ochoa, Paula, Guadalupe Quijada-Uribe, Gabriela Monsalvo-Velázquez, and Jesús Ramírez-Calderón. 2000. Unidades de Riego: La Otra Mitad del Sector Agrícola Bajo Riego. IWMI, Serie Latinoamericana No. 19. México, D.F. México: Instituto Internacional del Manejo del Agua.

Snyder, Richard (ed.). 1999. Institutional adaptation and innovation in rural Mexico. San Diego, USA: Center for U.S. Mexican Studies, University of California.

Van Koppen, Barbara. 1998. More jobs per drop: Targeting irrigation to poor women and men. Amsterdam, The Netherlands: Royal Tropical Institute KIT.

Wade, Robert. 1994. Village republics: Economic conditions for collective action in South India. San Francisco: Institute of Contemporary Studies Press.

Wester, Philippus, Borís Marañón-Pimentel, and Christopher A. Scott. 1999. Institutional responses to groundwater depletion: The aquifer management councils in the State of Guanajuato, Mexico. Paper presented at the International Symposium on Integrated Water Management in Agriculture. 16-18 June. Gómez Palacio: Mexico. 


\section{LIST OF CAPRi WORKING PAPERS}

01 Property Rights, Collective Action and Technologies for Natural Resource Management: A Conceptual Framework, by Anna Knox, Ruth Meinzen-Dick, and Peter Hazell, October 1998.

02 Assessing the Relationships Between Property Rights and Technology Adoption in Smallholder Agriculture: A Review of Issues and Empirical Methods, by Frank Place and Brent Swallow, April 2000.

03 Impact of Land Tenure and Socioeconomic Factors on Mountain Terrace Maintenance in Yemen, by A. Aw-Hassan, M. Alsanabani and A. Bamatraf, July 2000 .

04 Land Tenurial Systems and the Adoption of a Mucuna Planted Fallow in the Derived Savannas of West Africa, by Victor M. Manyong and Victorin A. Houndékon, July 2000.

05 Collective Action in Space: Assessing How Collective Action Varies Across an African Landscape, by Brent M. Swallow, Justine Wangila, Woudyalew Mulatu, Onyango Okello, and Nancy McCarthy, July 2000.

06 Land Tenure and the Adoption of Agricultural Technology in Haiti, by Glenn R. Smucker, T. Anderson White, and Michael Bannister, October 2000.

07 Collective Action in Ant Control, by Helle Munk Ravnborg, Ana Milena de la Cruz, María Del Pilar Guerrero, and Olaf Westermann, October 2000.

08 CAPRi Technical Workshop on Watershed Management Institutions: A Summary Paper, by Anna Knox and Subodh Gupta, October 2000.

09 The Role of Tenure in the Management of Trees at the Community Level: Theoretical and Empirical Analyses from Uganda and Malawi, by Frank Place and Keijiro Otsuka November 2000.

10 Collective Action and the Intensification of Cattle-Feeding Techniques a Village Case Study in Kenya's Coast Province, by Kimberly Swallow, November 2000. 
11 Collective Action, Property Rights, and Devolution of Natural Resource Management: Exchange of Knowledge and Implications for Policy, by Anna Knox and Ruth Meinzen-Dick, January 2001.

12 Land Dispute Resolution in Mozambique: Evidence and Institutions of Agroforestry Technology Adoption, by John Unruh, January 2001.

13 Between Market Failure, Policy Failure, and "Community Failure": Property Rights, Crop-Livestock Conflicts and the Adoption of Sustainable Land Use Practices in the Dry Area of Sri Lanka, by Regina Birner and Hasantha Gunaweera, March 2001.

14 Land Inheritance and Schooling in Matrilineal Societies: Evidence from Sumatra, by Agnes Quisumbing and Keijuro Otsuka, May 2001.

15 Tribes, State, and Technology Adoption in Arid Land Management, Syria, by Rae, J, Arab, G., Nordblom, T., Jani, K., and Gintzburger, G., June 2001.

16 The Effects of Scales, Flows, and Filters on Property Rights and Collective Action in Watershed Management, by Brent M. Swallow, Dennis P. Garrity, and Meine van Noordwijk, July 2001.

17 Evaluating Watershed Management Projects, by John Kerr and Kimberly Chung, August 2001.

18 Rethinking Rehabilitation: Socio-Ecology of Tanks and Water Harvesting in Rajasthan, North-West India, by Tushaar Shah and K. Vengama Raju, September 2001.

19 User Participation in Watershed Management and Research, by Nancy Johnson, Helle Munk Ravnborg, Olaf Westermann, and Kirsten Probst, September 2001. 